\title{
Telaah Atas Ilustrasi Buku Roesdi djeung Misnem sebagai Bacaan Murid-Murid Sekolah Rakyat di Jawa Barat sebelum Perang Dunia II
}

\author{
H.W. Setiawan, Irma Damajanti \& Prijanto Sunarto
}

Fakultas Senirupa dan Desain ITB

\begin{abstract}
This essay is a preliminary study on a series of book illustrations by a Dutch illustrator, the late W.K. de Bruin (1871-1945), which was printed in the book of Roesdi djeung Misnem: Boekoe Batjaan pikeun Moerid di Sakola Soenda (Roesdi and Misnem: A Reading Book for Sundanese School Pupils). As indicated by the sub-title, the so called "Buku Rusdi" (Book of Rusdi), which was written in collaboration between Sundanese and Dutch authors, is a reading book for children at Sakola Ra'yat or SR (literally "School for the Folk"), elementary school in West Java - Indonesia before the World War II. At the time, it used Sundanese as a medium of instruction. Amid previous studies on the history of book illustration in Indonesia, this study is a humble effort to consider some fundamental questions on the way illustrator represents people in visual forms, mainly on how the Dutch illustrator depicted Sundanese childhood in the course of European colonialism in Indonesia at the beginning of the twentieth century.
\end{abstract}

Keywords: Dutch Illustration; Elementary School in West Java; Representation.

\section{$1 \quad$ Pendahuluan}

Anak-anak Sunda dari kalangan rakyat kebanyakan di Jawa Barat, yang mengenyam pendidikan dasar sebelum Perang Dunia II, mengenal Roesdi djeung Misnem: Boekoe Batjaan pikeun Moerid ${ }^{2}$ di Sakola Soenda (Rusdi dan Misnem: Buku Bacaan untuk Murid-murid Sekolah Sunda). Buku tersebut dikarang oleh A.C. Deenik, pengarang Belanda, bersama R. Djajadiredja, pengarang Sunda, dan diterbitkan di Den Haag, Belanda, pada 1911. Isinya dilengkapi dengan ilustrasi karya ilustrator Belanda W.K. de Bruin (18711945). Buku tersebut terdiri atas 4 jilid. Sebagaimana yang tersurat dalam subjudulnya, buku tersebut merupakan bahan bacaan untuk murid-murid Sekolah Rakyat (SR)—-setingkat sekolah dasar kini_ di Jawa Barat, yang ketika itu menggunakan bahasa Sunda sebagai bahasa pengantarnya. Murid-murid SR, mulai dari kelas 2 hingga kelas 5, diharuskan membaca buku tersebut. 


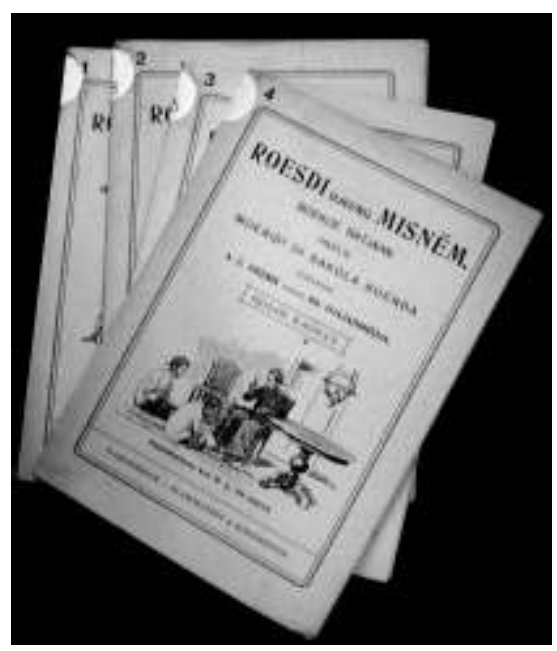

Gambar 1 Buku Roesdi djeung Misnem koleksi Bibliotheek KITLV, Leiden.

Kenangan akan buku tersebut, yang kiranya timbul dari keakraban sewaktu dibaca, tampaknya begitu kuat dan pada gilirannya diteruskan kepada satu dua generasi yang lahir seusai berakhirnya kolonialisme Belanda di Indonesia. Bahkan pada awal abad ke-21 ini, di lingkungan para penggemar buku-buku bacaan berbahasa Sunda, Roesdi djeung Misnem sesungguhnya masih beredar dan diperjualbelikan meski dalam bentuk fotokopi. Setidak-tidaknya, hingga dasawarsa 1970-an atau 1980-an tidak sedikit penduduk Tatar Sunda yang sempat mendengar dari orang-orang tua di sekeliling mereka, terutama yang pernah mengalami zaman pemerintah kolonial Belanda, menyebut-nyebut "Buku Rusdi" dalam perbincangan sehari-hari. Seakan-akan "Buku Rusdi" telah menjadi rujukan pengetahuan kolektif di Tatar Sunda pada suatu masa, dan sudah pasti telah menjadi bagian penting dari masa kanak-kanak banyak orang. Dalam kata-kata seorang seniman dan penulis dari Bandung, Roesdi djeung Misnem merupakan "buku bacaan bahasa Sunda 'legendaris' [1]. Sementara itu seorang sastrawan Indonesia terkemuka yang lahir pada 1938 pernah menulis esai tentang kenangan pribadinya atas buku tersebut pada 1957, mengatakan:

Mun aja nu nanja ka kuring: "Buku naon nu pangpikaresepeunana djeung pangalusna pikeun batjaan barudak di Sakola Ra'jat?”; moal hamham deui kuring tangtu ngadjawab: "Buku Roesdi djeung Misnem.”

Bila ada orang yang bertanya kepada saya: "Buku apa yang paling saya sukai dan paling bagus sebagai bacaan anak-anak di Sekolah 
Rakyat (Dasar)?"; tak pelak lagi saya tentu menjawab: "Buku Roesdi djeung Misnem." [2]

Tidaklah mengherankan apabila keterangan mengenai buku tersebut juga menjadi entri tersendiri dalam Ensiklopedi Sunda Bahkan dalam ensiklopedi tersebut dikatakan bahwa Roesdi djeung Misnem dapat dijadikan "bahan kajian kemasyarakatan" karena isinya diyakini sesuai dengan keadaan masyarakat Sunda (di perkampungan) pada masanya.

Buku Roesdi djeung Misnem menuturkan berbagai pengalaman sehari-hari kakak beradik Rusdi dan Misnem di lingkungan sekitar rumah mereka di kampung. Tuturannya dituangkan dengan bahasa pergaulan sehari-hari yang lazim digunakan oleh masyarakat Sunda kebanyakan pada masa itu. Gaya penyajiannya bersahaja, bahkan seringkali terasa jenaka, selaras dengan dunia kehidupan anak-anak.

Sedemikian eratnya buku Roesdi djeung Misnem melekat pada pikiran dan kenangan masyarakat yang pernah membacanya, kiranya tidak hanya dimungkinkan oleh muatan verbalnya, melainkan juga dimungkinkan oleh muatan visualnya. Kata dan gambar berjalin membentuk pikiran dan kenangan. Namun, tampaknya, selama ini banyak orang yang mengenang buku tersebut cenderung hanya memikirkan narasinya, dan kurang mengindahkan ilustrasinya. Padahal, bagaimanapun, ilustrasi naturalistis yang terdapat dalam buku tersebut tidak dapat diabaikan. Imajinasi anak-anak Sunda sebelum Perang Dunia II tentang sosok kakak beradik Rusdi dan Misnem beserta seluk beluk dunia kehidupan di sekitarnya tentu tidak hanya dipengaruhi oleh narasi, melainkan juga oleh ilustrasi. Dengan kata lain, rangkaian gambar itu tampaknya telah menjadi sejenis ilustrasi bagi pikiran dan kenangan kolektif.

Dengan demikian, rangkaian ilustrasi karya W.K. de Bruin dalam buku tersebut kiranya dapat dikaji sebagai sebentuk hasil kreasi di bidang seni ilustrasi yang telah ikut memengaruhi pikiran dan kenangan kolektif di Indonesia, dan dengan sendirinya telah menjadi bagian tersendiri dari sejarah seni ilustrasi di negeri ini.

\section{$2 \quad$ Studi Ilustrasi: Mengamati W.K.de Bruin}

Sejauh ini, khususnya di Indonesia, belum ada penelitian yang secara khusus meninjau rangkaian ilustrasi karya W.K. de Bruin dalam buku Roesdi djeung Misnem. Begitu pula pengetahuan (orang Indonesia) mengenai sosok dan karya W.K. de Bruin di bidang seni ilustrasi, yang di antaranya berkaitan dengan penggambaran alam dan manusia Indonesia pada zaman kolonial, kiranya masih kurang memadai. Dalam Lexicon of Foreign Artists who Visualized Indonesia 
(1600-1950) susunan Leo Haks dan Guus Maris, misalnya, hanya disebutkan bahwa W.K. de Bruin "membuat ilustrasi mengenai Indonesia untuk sejumlah buku anak-anak seperti Indische Sprookjes (Rijswijk, 1923) karangan T.J.A. Hilgers dan Mijn Eerste Leesboek (Rijswijk, ca.1915) karangan F. Viersen." [3].

Namun hal itu tidak berarti bahwa selama ini sama sekali tidak ada upaya untuk meneliti sejarah seni ilustrasi di Indonesia yang menyinggung-nyinggung sosok dan karya W.K. de Bruin. Di antara beberapa hasil penelitian mengenai sejarah seni ilustrasi di Indonesia, terdapat karya penting dari Haryadi Suadi, Onong Nugraha: Sebuah Riak dalam Gelombang Sejarah Seni Ilustrasi di Indonesia yang diterbitkan pada tahun 2000. Sebagaimana yang tersurat dalam judulnya, buku itu memusatkan perhatian pada sosok dan karya mendiang Onong Muhammad Nugraha Sastraatmadja (1933-2001), ilustrator dan desainer terkemuka yang antara lain dikenal lewat rangkaian ilustrasinya dalam sejumlah majalah, khususnya majalah Sunda. Dalam buku itu lebih dari sekali Haryadi menyebutkan bahwa ilustrasi karya Onong Nugraha "terpengaruh W.K. de Bruin"[4]. Meskipun buku ini, dengan caranya sendiri, kiranya telah turut menegaskan peran yang dimainkan oleh ilustrasi karya W.K. de Bruin dalam sejarah seni ilustrasi di Indonesia, tetapi sosok dan karya W.K. de Bruin sendiri baru disinggung-singgung sambil lalu.

Di Belanda sendiri penelitian mengenai sosok dan karya W.K. de Bruin tampaknya belum banyak. Di antara bahan-bahan mengenai hal itu yang tersedia sejauh ini, ada buku Brood op de Leesplank: Zes Illustratoren in Dienst Van Het Onderwijs: C. Jetses, J.H. Isings, Tj. Bottema, W.K. de Bruin, B. Beuninck, J. Gabrielse (Roti pada Papan Pengajaran: Enam ilustrator yang Bekerja di Bidang Pendidikan: C. Jetses, J.H. Isings, Tj. Bottema, W.K. de Bruin, B. Beuninck, J. Gabrielse) karya Jacqueline Burgers (1977). Buku ini turut menyediakan informasi penting perihal sosok dan karya W.K. de Bruin, tetapi titik tolaknya lebih terpaut pada sejarah seni ilustrasi di Belanda, khususnya yang berkaitan dengan sejarah pengajaran tingkat dasar di negeri itu.

Hasil penelitian lainnya yang juga penting diperhatikan dalam hal ini adalah $\mathrm{Als}$ de Muren Konden Spreken: Schoolwandplaten en de geschiedenis van het Belgisch lager onderwijs (Seandainya Dinding Bisa Bicara: Papan Pengajaran dan Sejarah Pendidikan Dasar di Belgia), disertasi karya Karl Catteeuw yang dipertahankan di Faculteit Psychologische Wetenschappen, Katholieke Universiteit Leuven, Belgia, tahun 2005. Dalam salah satu pokok bahasannya, Catteeuw menyoroti Nederlandse ontwerpers (para perancang grafis Belanda), yang antara lain menyinggung-nyinggung sosok dan karya W. K. de Bruin pula. Namun, sebagaimana buku karya Jacqueline Burgers, disertasi karya Karl 
Catteeuw menitikberatkan perhatiannya pada seni ilustrasi dalam hubungannya dengan sejarah pendidikan di Eropa.

\section{Memetakan Permasalahan: De Bruin dan Orang Sunda}

Ilustrasi adalah gambar yang diabdikan pada narasi. Gambar itu sendiri bisa berbicara. Bahkan kemunculan gambar kiranya menjalin pertautan yang erat dengan kebutuhan manusiawi akan adanya cerita. Ketika gambar muncul, pada saat itulah bidang yang tadinya lengang dan hampa bisa berbicara. Terlebihlebih gambar yang memang dirancang sebagai ilustrasi dari sesusun teks verbal, sudah barang tentu memiliki pertautan yang begitu erat dengan cerita.

Ilustrasi adalah gambar yang disajikan bersama teks, sebagai bagian dari atau pendamping untuk teks, baik untuk menambah daya tarik teks maupun untuk memperjelas maksud teks. Ilustrasi pada dasarnya turut menafsirkan teks, atau sekurang-kurangnya berupaya memperhidup teks melalui citra visual. Dalam hal ini ilustrasi dapat dibedakan dengan iluminasi meskipun pada umumnya dan dalam perkembangan sejarahnya ilustrasi dan iluminasi berjalan beriringan bahkan berpautan sedemikian eratnya. Namun untuk kepentingan analitis, keduanya bisa dibedakan satu dari yang lainnya. Jika iluminasi merupakan gambar yang cenderung hanya menjadi dekorasi bagi teks, ilustrasi merupakan gambar yang cenderung ikut menjadi interpretasi atas teks.

Gambar-gambar tersebut-yang pada dirinya sendiri dilekatkan pada narasi yang tertuang dalam buku tersebut - dapat dikaji sedemikian rupa sehingga dapatlah diuraikan sangkut-pautnya dengan berbagai masalah yang lebih luas, terutama menyangkut keadaan masyarakat di Tatar Sunda - dan masyarakat Indonesia pada umumnya - sebelum Perang Dunia II. Di dalam maksud seperti itu terkandung asumsi bahwa rangkaian gambar itu tidak lahir begitu saja, melainkan merupakan suatu perwujudan tersendiri dari sesusun gagasan, pandangan, atau tata hubungan kemasyarakatan tertentu. Dengan kata lain, telaah ini berupaya menekankan implikasi sosial politik dari serangkaian gambar ilustrasi.

Dalam kerangka pemikiran seperti itu, sedikitnya ada tiga pokok permasalahan . Ketiganya dapat diperinci sebagai berikut:

1. Kecenderungan artistik seperti apa yang turut membentuk pencitraan orang dan alam kehidupan Sunda dalam gambar ilustrasi karya W.K. de Bruin dalam buku Roesdi djeung Misnem? Dalam hal ini perhatian dapat diarahkan pada kompleksitas gaya, aliran, atau kecenderungan artistik yang mempengaruhi proses kreatif pembuatan gambar-gambar ilustrasi. 
2. Kandungan-kandungan nilai apa saja yang tersirat dalam gambar ilustrasi karya W.K. de Bruin dalam buku Roesdi djeung Misnem? Dalam hal ini, objek gambar serta cara objek tersebut dihadirkan dalam gambar kiranya dapat dipertautkan dengan pandangan-pandangan dominan yang memengaruhi cara pandang kolonial atas masyarakat jajahan.

3. Bagaimana orang dan alam Sunda dicitrakan oleh W.K. de Bruin dalam buku Roesdi djeung Misnem? Dalam hal ini perhatian dapat diarahkan pada pada raut, latar, tema, sudut pandang dll. sebagaimana yang terlihat dalam gambar.

Dengan demikian, perhatian ditekankan pada seluk beluk artistik dari rangkaian ilustrasi tersebut, sedangkan masalah-masalah yang berkaitan dengan kebijakan pendidikan di Indonesia pada zaman kolonial hanya akan dijadikan semacam konteks kesejarahannya. Dengan kata lain, telaah ini berupaya meninjau secara kritis cara manusia dan dunia kehidupan Sunda direpresentasikan melalui serangkaian gambar dan teks verbal dalam kerangka kebijakan pendidikan pada zaman kolonial.

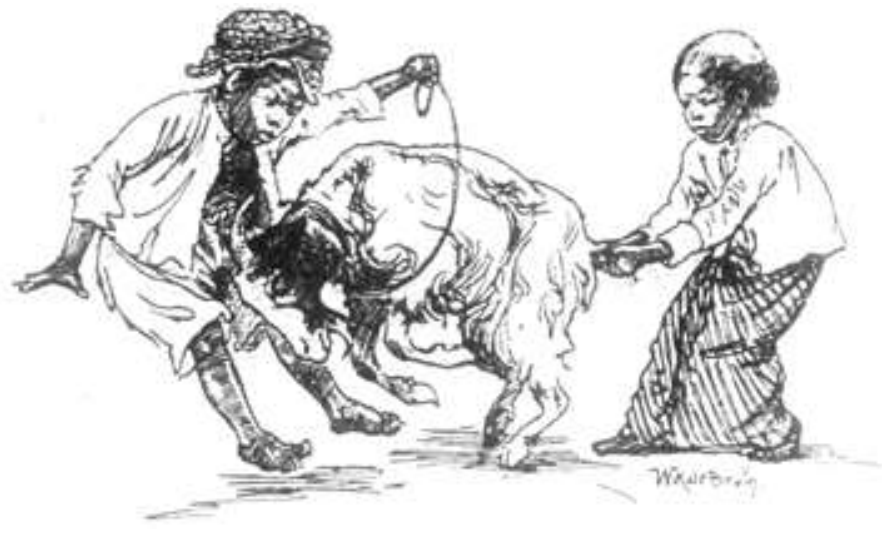

Gambar 2 Salah satu ilustrasi karya W.K. de Bruin dalam Roesdi djeung Misnem.

Sebagaimana yang telah disinggung-singgung di atas, buku tersebut terdiri atas 4 jilid. Ilustrasi karya W.K. de Bruin dalam buku tersebut terdiri atas 38 gambar dalam Jilid I, 40 gambar dalam Jilid II, 41 gambar dalam Jilid III, dan 31 gambar dalam Jilid IV, ditambah 2 gambar pada tiap-tiap jilid yang masingmasing dimuat dalam jilid muka dan jilid belakang. Dengan demikian, keempat jilid buku tersebut memuat 158 gambar. Jumlah gambar sebanyak itu kiranya akan menjadi terlampau banyak untuk dipaparkan dan dianalisis satu demi satu. Oleh karena itu, alih-alih mencakup seluruh gambar tersebut, telaah ini kiranya 
dapat memperhatikan beberapa gambar di antaranya saja, yang diambil dari tiap-tiap jilid yang dianggap representatif.

\section{4 "Buku Rusdi” sebagai Bacaan Murid Sekolah Rakyat}

Ada dua kategori buku yang diperkenalkan kepada murid-murid sekolah rakyat di wilayah Hindia Belanda pada zaman kolonial, terutama dalam mata pelajaran bahasa sebagaimana yang dikenal hingga kini, yakni buku pelajaran (leerboek) dan buku bacaan (leesboek). Jika buku pelajaran cenderung bersifat didaktis, dalam arti menekankan pengetahuan dan keterampilan anak didik, buku bacaan cenderung bersifat impresif, dalam arti menggugah minat anak-anak untuk gemar membaca dan menghayati isi bacaan.

Roesdi djeung Misnem, sebagaimana yang tersurat dalam subjudulnya, tergolong ke dalam kategori buku bacaan. Buku yang terdiri atas empat jilid ini, pada setiap jilidnya menceritakan serba-serbi kehidupan sehari-hari kakak beradik Rusdi dan Misnem, yang diselingi dengan berbagai cerita singkat, dongeng, gambaran kehidupan di tempat-tempat yang jauh, dsb., tak ubahnya dengan rangkaian cerita bersambung yang dituturkan dari sudut pandang orang ketiga. Secara keseluruhan, alur penceritaan buku ini sejalan dengan perkembangan diri Rusdi sebagai protagonisnya, mulai dari masa prasekolah di kampung hingga memasuki masa sekolah di kota. Barangkali karena daya tarik isinyalah, yang terasa benar menekankan aspek cerita, buku ini dapat dikatakan agak bertahan menghadapi perubahan zaman sekalipun sudah begitu lama tidak lagi digunakan sebagai bahan bacaan di sekolah dasar. Tidak mustahil pula, buku inilah yang menjadi prototip bagi buku-buku bacaan berbahasa Sunda buat anak-anak yang bermunculan kemudian.

Dewasa ini buku Roesdi djeung Misnem tersimpan antara lain di Perpustakaan Nasional, Jakarta; Mattheson Library, Monash University, Melbourne, Australia; dan Bibliotheek KITLV, Leiden, Belanda. Koleksi tersebut terawat secara baik. Di Bibliotheek KITLV, misalnya, jilid dan halaman buku-buku itu tetap utuh, dan kondisi kertasnya tampak masih putih, bersih dan agak licin [5]. Sementara di Mattheson Library, buku Roesdi djeung Misnem secara khusus disimpan dalam "Rare Books Section" (Kelompok Buku Langka) [6]. Akan tetapi belum diketahui secara pasti, kapan buku 'Rusdi djeung Misnem' terbit untuk pertama kali. Dalam setiap edisinya tidak tercantum keterangan mengenai tahun publikasinya. Berdasarkan "Inventarisasi dan Dokumentasi Literatur dan Sumber tentang Kebudayaan Sunda" susunan Edi S. Ekadjati dkk. dari Tim Peneliti Lembaga Kebudayaan Universitas Padjadjaran (1983/1984), diketahui bahwa A.C. Deenik dan R. Djajadiredja menulis Boekoe batjaan pikeun moeridmoerid di Sakola Soenda, yang dilengkapi dengan ilustrasi dan terdiri atas 4 jilid. Buku tersebut tercatat terbit di Den Haag pada 1911. Berdasarkan sumber 
yang sama juga diketahui bahwa A.C. Deenik dan R. Djajadiredja menulis Roesdi djeung Misnem: Boekoe batjaan pikeun moerid-moerid di Sakola Soenda, yang juga disertai dengan ilustrasi dan terdiri atas 4 jilid. Buku tersebut tercatat terbit di Den Haag pada 1930 (jilid I cetakan ke-5, jilid II cet. ke-4, jilid III cet ke-3, jilid IV cet. ke-3). Untuk sementara, dapat diduga bahwa buku Roesdi djeung Misnem pertama kali terbit pada 1911, tapi pada mulanya tidak memakai judul "Roesdi djeung Misnem" melainkan "Boekoe batjaan pikeun moerid-moerid di Sakola Soenda" sebagaimana yang menjadi subjudulnya kemudian.

Sesungguhnya, Roesdi djeung Misnem bukanlah satu-satunya buku bacaan bagi murid-murid sekolah rakyat di Jawa Barat sebelum Perang Dunia II. Apalagi pada zaman kolonial ada pemisahan sekolah berdasarkan perbedaan golongan sosial tempat murid-murid berasal. Anak-anak dari golongan sosial menak atau bangsawan tidak berada dalam satu sekolah dengan anak-anak dari golongan sosial cacah atau rakyat jelata. Mata pelajaran yang mereka dapatkan pun berlainan. "Buku Rusdi" tampaknya dialamatkan kepada murid-murid sekolah dasar yang berasal dari golongan rakyat jelata.

Di samping "Buku Rusdi”, terdapat buku-buku sejenis - bahkan dengan bahasa dan pola serta khalayak pembaca yang sebanding-yang dapat dikatakan sezaman dengan buku tersebut. Salah satu di antara adalah buku buku Panggelar Boedi karangan W. Keizer, pengarang Belanda, yang ilustrasinya juga dibuat oleh W.K. de Bruin. Ada pula buku Mangle: nya eta Roepa-Roepa Tjarita reudjeung Tjonto, pikeun Sakola Soenda (Bungarampai: yaitu Beragam Cerita dan Contoh, untuk Sekolah Sunda) (Cet. ke-8, 1913) karangan W. van Gelder terbitan De Swart \& Zoon, Den Haag, Belanda. Buku tersebut juga dilengkapi dengan gambar-gambar, di antaranya berupa gambar-gambar realistis yang diolah dari foto hitam putih yang diwarnai dengan cat air dan dicetak dalam bentuk full-colour. Namun apabila dibandingkan dengan bukubuku sejenis yang terbit pada masanya, Roesdi djeung Misnem tampaknya lebih populer. Sebagai gambaran dapat disebutkan bahwa salah seorang sastrawan Sunda terkemuka di Bandung, yang lahir pada 1935 dan ketika ia duduk di sekolah dasar tidak membaca buku tersebut, memiliki satu bundel fotokopian Roesdi djeung Misnem, sama dengan yang beredar di lingkungan para penggemar buku berbahasa Sunda dewasa ini.

\section{Raden Djajadiredja sebagai Penulis "Buku Rusdi"}

Raden Kanduruan Djajadiredja (1882-1942) adalah guru yang tinggal dan bekerja di Bandung. Ia lahir dan besar di Ciamis, Jawa Barat, dan setelah wafat pada usia 60 tahun dikebumikan di kampung halamannya. Ia menikah dengan R. Gartinah Bratadisastra yang berasal dari Panjalu, Ciamis. Pernikahan mereka 
dikarunia sebelas anak, tiga di antaranya meninggal sewaktu masih kecil. Di antara anak-anaknya yang tumbuh dan berkembang di bidangnya masingmasing adalah Inu Djajadiredja (anak tertua), Dr. Sjarif Djajadiredja, Hj. Titi Djajadiredja (anak kelima), Itje Djajadiredja (anak keenam). Djajadiredja sekeluarga tinggal di J1 Pungkur 29, Bandung.[7]

Pada dasawarsa 1920-an Djajadiredja mengajar di "Sakola Ménak" (Mosvia) di Tegallega dan "Sakola Raja" (HIK) di Jl Jawa, Bandung. Mata pelajaran yang disampaikan olehnya adalah bahasa Sunda dan menggambar. Di luar sekolah, ia juga memberikan les bahasa dan tatakrama Sunda untuk orang-orang Belanda. Ada kalanya ia mengisi waktu luang dengan melukis, dan ia pernah mendesain panggung untuk sebuah kegiatan Bank Himpunan Saudara. Oleh cucu-cucunya, sering ia dijuluki sebagai "Eyang Gambar" (kakek yang pandai menggambar). Menjelang zaman pendudukan Jepang, Djajadiredja pensiun, kemudian mengajar di MULO Pasundan, di Bandung.

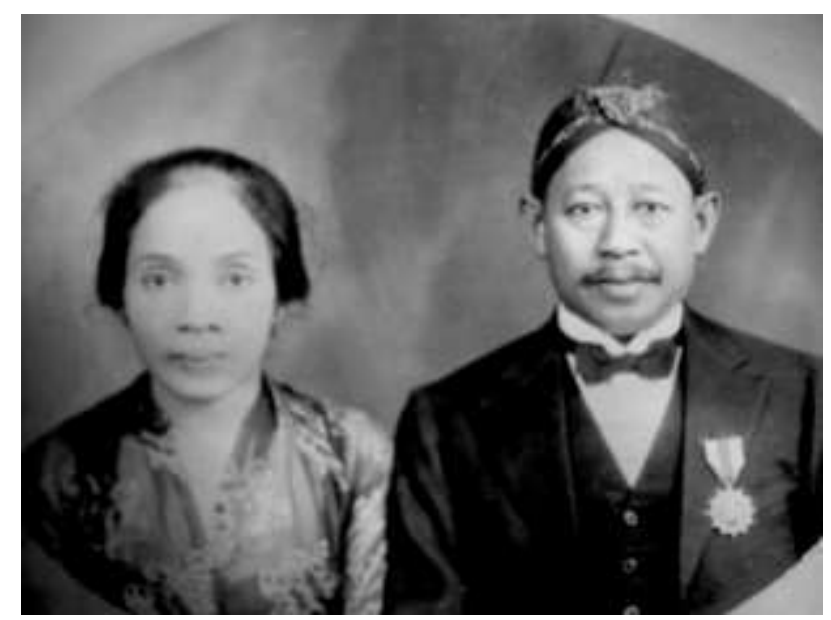

Gambar 3 Djajadiredja bersama R. Gartinah (foto: dok. Keluarga Djajadiredja)

Selain dikenal sebagai guru, Djajadiredja juga merupakan penulis yang produktif. Jenis dan tema bukunya bermacam-macam, mulai dari buku pelajaran bahasa hingga buku petunjuk memelihara kuda serta buku perihal hujan dan petir. Sudah barang tentu, Roesdi djeung Misnem, yang ia tulis bersama A.C. Deenik, adalah karyanya yang sangat terkenal. Bahkan oleh sebagian rekannya, ia sering dijuluki sebagai "Si Rusdi" atau "Bapa Gembru" (tentu saja, mengacu kepada tokoh Ujang Rusdi yang dijuluki sebagai Ujang Gembru karena berperut gemuk, dan kebetulan sosok Djajadiredja sendiri terbilang gempal). Ia menulis sejumlah buku baik dalam bahasa Sunda maupun dalam bahasa Melayu, baik 
sendirian maupun bekerja sama dengan pengarang lain. Ada kalanya ia pun menulis untuk majalah. Makalahnya yang disampaikan dalam Kongres Bahasa Sunda pada 1927 kemudian dimuat dalam majalah Poesaka Soenda (No. 8-9, Augustus-September 1927, Tahun ke-5) dengan judul "Praeadvies R. Djajadiredja"[8]. Selain Roesdi djeung Misnem, buku-buku karangannya antara lain Batjaan Mimiti (4 jilid, bersama T.A. Gaikhorst dan N. Titus), Toedoeh Djalan, dan Mitra Poetra (menggunakan aksara Sunda) [9].

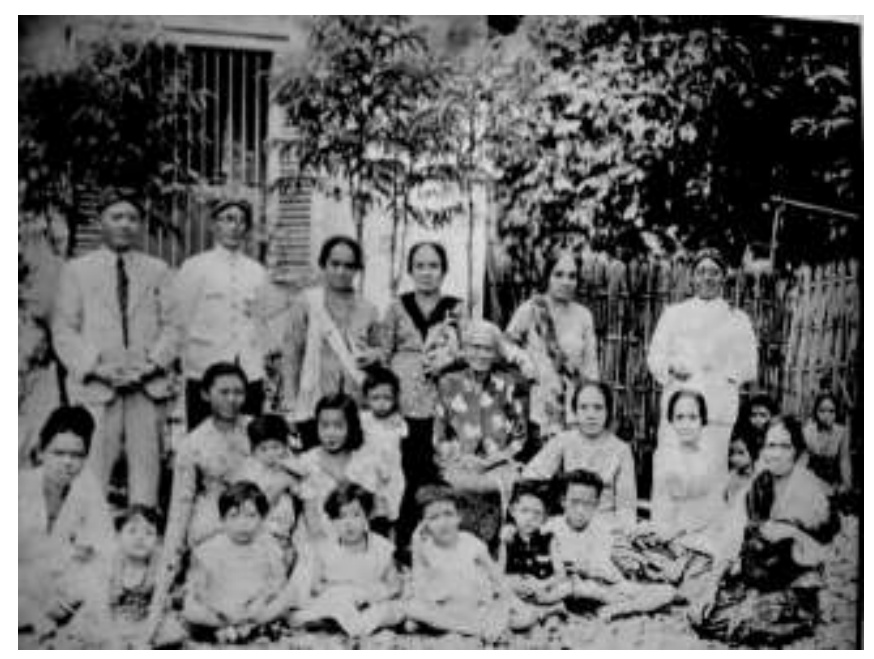

Gambar 4 R. Djajadiredja (berdiri di sebelah kanan) bersama keluarga dan bekas murid-muridnya (Foto: Dok. Keluarga R. Djajadiredja)

\section{6 de Bruin sebagai Ilustrator "Buku Rusdi"}

Tentang W.K. de Bruin, sayang sekali, tidak banyak keterangan yang kita ketahui. Dalam bukunya, Brood op de Leesplank, Jacqueline Burgers hanya menerangkan sosok ilustrator de Bruin sebagai berikut:

De enige gegevens die we hebben over Wilhelmus Karel de Bruin zijn dat hij werd geboren in 1871 in Den Haag als zoon van een steendrukker en dat hij Evangelisch Luthers onderwijzer bij het openbaar lager onderwijs was en later tekenleraar. Hij stierf in 1945.

Data yang kita miliki mengenai Wilhelmus Karel de Bruin hanya menyebutkan bahwa dia lahir pada 1871 di Den Haag sebagai anak pengelola percetakan dan bahwa dia mula-mula bekerja sebagai 
guru sekolah dasar Evangelis Lutheran, kemudian menjadi juru gambar. Dia wafat pada 1945. [10]

Alih-alih membicarakan sosok De Bruin, Burgers lebih banyak membahas karya ilustrator dan guru gambar dari Den Haag itu. Secara sambil lalu Burgers menduga bahwa De Bruin masuk ke lingkungan pendidikan di Den Haag diperkirakan atas ajakan Gerard Jan Ligthart (1859 - 1916). Ligthart sendiri adalah guru dan ahli pendidikan yang terpandang di Belanda pada masanya. Pada 1885, ketika ia diangkat sebagai Kepala Sekolah Rendah Terbuka di Den Haag, Ligthart memanfaatkan alat bantu pengajaran berupa pelat gambar (schoolplaat) yang mengandung cerita dan diberi gambar. Sebagian pelat gambar itu digambari oleh De Bruin, dan sebagian lagi oleh rekannya, Cornelis Jetses (1873-1955) [11].

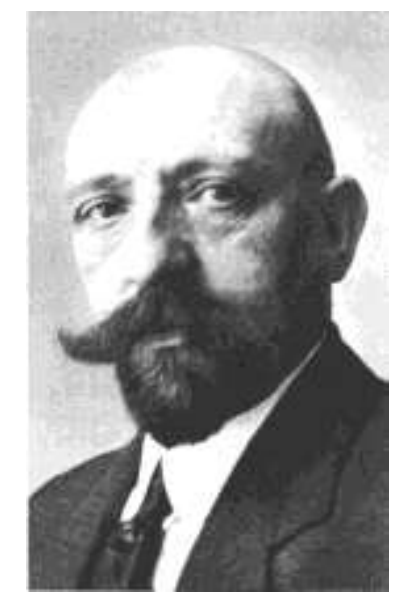

Gambar 5 W.K. de Bruin (repro Brood op de Leesplank).

Cukup banyak buku bacaan anak-anak dalam bahasa Belanda yang digambari oleh De Bruin. Dapat kita sebutkan antara lain De Wereld in karya Jan Ligthart dan Hendricus Scheepstra, Het Volle Leven (1905-1909) karya Jan Ligthart, Hendricus Scheepstra dan W. Walstra, Op Rozenhof karya Wagenvoort, $O p$ de fiets door Nederland, dan Uit Vroeger Eeuwen. Di antara buku-buku berbasa Belanda yang digambari oleh W.K. de Bruin, ada pula yang digunakan di wilayah Hindia Belanda seperti yang disebut-sebut dalam Lexicon of Foreign Artists who Visualized Indonesia (1600-1950), yakni Indische Sprookjes (Rijswijk, 1923) karangan T.J.A. Hilgers dan Mijn Eerste Leesboek (Rijswijk, ca. 1915) karangan F. Viersen. Selain itu, De Bruin juga membuat ilustrasi untuk buku-buku bacaan anak-anak yang menggunakan bahasa pribumi, bukan hanya yang berbahasa Sunda tapi juga yang berbahasa Jawa dan Madura. Burgers hanya menyebut-nyebut Kembang Setaman karya A.C. Deenik sebagai 
buku anak-anak berbahasa pribumi Hindia Belanda yang digambari oleh De Bruin. Padahal untuk buku-buku berbahasa Sunda saja, ilustrasi karya De Bruin bukan hanya terdapat dalam Roesdi djeung Misnem, tapi juga dalam Panggelar Boedi karangan W. Keizer.

Gambar-gambar karya De Bruin, baik yang menggunakan cat air maupun yang berupa gambar hitam putih dibuat dengan pulpen, mampu menangkap karakter, gerak, latar dan suasana dengan amat hidup. Seraya mengakui kemahiran De Bruin, Burgers berpendapat sebagai berikut:

W.K. de Bruin is onmiskenbaar beïnvloed door Hoynck van Papendrecht. Zijn beste aqurellen zijn die voor Uit Vroeger Eeuwen, zoals 'De Prins van Oranje bij Waterloo' en 'Jan Willem Friso bij Malplaquet'. Vooral bij de laatse voorstelling valt er een levendigheid op, die De Bruin alleen maar kan treffen in massale en/of gevechtscènes.

[...]De Bruin verdient meer erkenning dan hij heeft, vanwege zijn vele goede illustaties voor schoolboeken.

W.K. de Bruin jelas dipengaruhi oleh Hoynck van Papendrecht. Karya-karya terbaiknya yang memanfaatkan cat air terdapat dalam Uit Vroeger Eeuwen (Dari Abad yang telah Lewat), semisal 'Pangeran Oranye di Waterloo' dan 'Jan Willem Friso di Malplaquet'. Khususnya, gambar yang memperlihatkan air terjun yang sangat hidup, yang hanya dapat dilihat dalam karya De Bruin dalam gambar-gambar yang massif dan/atau menonjol.

[...] De Bruin selayaknya mendapatkan pengakuan yang lebih besar, mengingat ilustrasi-ilustrasi karyanya cukup bagus buat buku-buku pelajaran. [12]

Sebagian besar gambar de Bruin merupakan drawing yang dibuat dengan pulpen atau sangat boleh jadi merupakan etsa. Berarsir tipis dan berirama menunjukkan kepiawaian di dalam upaya menangkap rincian sosok, bidang, ruang, latar dan suasana yang digambar. Beberapa gambar lainnya dibuat dengan cat air di atas kertas, terutama gambar-gambar yang tidak begitu menuntut adanya perhatian pada rincian keadaan, semisal gambar suasana di dalam rumah pada malam hari. De Bruin juga mahir menggambar siluet. Dalam hal tema atau motifnya, beberapa gambar yang terdapat dalam seri Roesdi djeung Misnem bersifat dekoratif, misalnya dengan mengolah pola lukisan batik atau karakter wayang dengan menekankan bentuk-bentuk yang simetris. Ada pula sejumlah gambar yang mengandung penggabungan dua perspektif, dalam 
arti gambar yang satu menjadi insert bagi gambar yang lain, yang dibuat sejalan dengan maksud teks yang isinya menerangkan atau memerikan sesuatu. Namun, sebagian besar gambar karya De Bruin dalam serial ini diupayakan untuk menangkap situasi pribumi di Hindia Belanda dalam kehidupan sehari-hari dan karakter-karakter nyata yang hidup di dalamnya, terutama karakter anak-anak, selaras dengan maksud teksnya.

Sebegitu jauh, belum dapat dipastikan pernahkah De Bruin berkunjung ke Indonesia? Untuk mendapatkan gambaran perihal cara De Bruin memvisualisasikan orang Sunda dalam "Buku Rusdi", berikut ini akan dikemukakan sekelumit analisis mengenai sosok tokoh Rusdi dan Misnem dalam buku tersebut.

\section{$7 \quad$ Sosok Rusdi dan Misnem}

Ujang Rusdi alias Ujang Gembru, tokoh utama dalam buku Roesdi djeung Misnem, diceritakan berumur tujuh tahun dan mempunyai seorang adik bernama Misnem. Sosok Rusdi dan Misnem antara lain dapat dilihat dalam gambar di bawah.

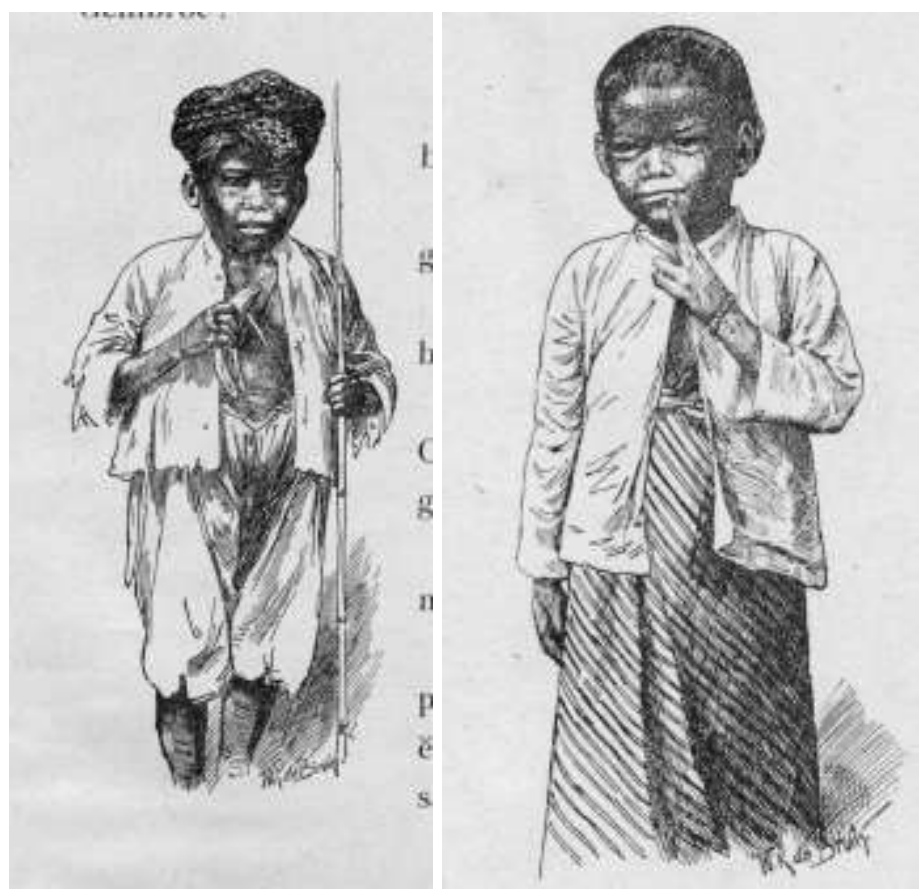

Gambar 6 Sosok Rusdi dan Misnem (repro Roesdi djeung Misnem). 
Di samping gambar tersebut terdapat deskripsi mengenai sosok Rusdi dari A.C. Deenik dan R. Djajadiredja, pengarang buku tersebut. Kedua pengarang tersebut memperkenalkan Rusdi kepada para pembaca (dengan ejaan bahasa Sunda dahulu kala) sebagai berikut:

"Ka dieu, baroedak!

Maraneh geus papanggih djeung Oedjang Gëmbroe?

Saha nu tatjan?

Geura ilikan ieu gambarna!

Euleuh! euleuh!......geuning lintoeh nakèr.

Pipina mani karebi beuteungna mani njěmploe.

Poegoeh! Pang disěbut Oedjang Gěmbroe oge, da gěde beuteung.

Ari ngaranna noe saenjana mah Oedjang Roesdi.

"Dadaharanana oenggal poe beak doea kati," tjeuk èmana. Ari deungeun sangoe salawasna sok meakkeun batoer. Barang hakanna taja eureunna. Ti barang hoedang něpi ka doeg hees, soengoetna teu petot-petot njapek.

Sakoer kahakanan noe kapanggih dihoeapkeun.

Tah kitoe sababna pang lintoeh teh!

Sore isoek teu aja deui gawena, ngan oelin bae di kěbon.

Toeh geuning: badjoena, tjalanana, mani rarawing, sok tikakarait kana pagěr.

Koe kolotna papakeanana tara pati dioeroes, bongan gagabah.

Omong èmana: 'Keun bae soegan kapokeun.'”

"Ke marilah, anak-anak!

Pernahkah kalian bertemu dengan Ujang Gembru?

Siapa yang belum pernah?

Coba lihat gambarnya!

Wah! wah!... betapa gemuknya.

Pipinya tembem perutnya buncit.

Tentu! Ia disebut Ujang Gembru karena perutnya besar.

Sebenarnya, namanya adalah Ujang Rusdi.

"Makannya tiap hari menghabiskan dua liter," kata ibunya. Lauk pauknya pun dihabiskan sendiri. Tiada hentinya dia makan. Sejak bangun tidur hingga tidur lagi, mulutnya terus saja mengunyah. Makanan apapun yang dia temukan pasti disantap.

Nah, itu sebabnya dia gemuk!

Siang malam tiada lagi kerjanya, hanya bermain di kebun.

Lihatlah: bajunya, celananya, compang-camping, karena sering tersangkut pagar.

Oleh orang tuanya, pakaiannya tidak begitu diperhatikan, sebab seenaknya. 
Kata ibunya: 'Biar saja, siapa tahu dia kapok.' [13]

Sebagaimana yang terlihat dalam gambar di atas, deskripsi mengenai sosok Rusdi divisualisasikan melalui gambar seorang anak lelaki yang tubuhnya pendek dan gemuk. Kulitna gelap, terutama pada bagian tangan dan kaki. Wajahnya tirus, dengan hidung pesek dan mulut lebar serta agak menganga. Matanya memandang ke depan, sedangkan jidatnya tampak agak berkerut. Jika dipandang selintas, air mukanya tampak jauh lebih tua daripada umurnya. Ia mengenakan ikat kepala yang tampaknya terbuat dari kain batik, sehingga rambutnya tertutup tapi telinganya terbuka. Baju dan celananya robek-robek. Bajunya tidak dikancingkan, hingga dadanya terbuka. Tampaknya, baju yang ia kenakan terlalu sempit untuk badan yang gemuk. Ujung celananya menutupi lutut, sedangkan pangkalnya hampir menutupi pusar. Pengikat celana menggunakan dengan seutas tali pada bagian pangkalnya yang diikatkan di selingkar perut. Tangan kirinya memegang sebatang tongkat bambu yang agak meruncing pada bagian ujungnya, sedangkan tangan kanannya memegang sebutir buah pisang yang kulit salah satu ujungnya tampak sudah terkelupas.

Gambar di atas dibuat dengan tinta Cina berwarna hitam di atas kertas putih. Kepekatan, tekstur dan permainan cahaya diwujudkan dengan mengandalkan teknik arsiran ke berbagai arah. Gaya menggambarnya naturalistis dengan menekankan rincian objek gambar hingga ke bagian-bagian yang terkecil. Namun, patut dicatat, de Bruin tidak menggambarkan sosok Rusdi hingga ke ujung kakinya. Kita tidak melihat tumit, telapak dan jari kaki Rusdi. Meskipun demikian, secara umum dapat dikatakan bahwa de Bruin menampilkan sosok Rusdi secara "utuh". Latar belakang hampir tidak digambarkan sama sekali, kecuali sedikit bayang-bayang tubuh Rusdi yang agak memanjang ke belakang. Cahaya tersorot dari latar depan dengan arah agak menyamping. Dengan demikian, sosok Rusdi tampak menonjol. Adapun jati diri pembuat gambar, yakni W.K. de Bruin, dibubuhkan di bawah gambar, menyatu dengan arsiran bayang-bayang tubuh Rusdi.

Untuk mengamati gambar di atas secara lebih terperinci, kiranya ada baiknya mencari bahan perbandingan berupa potret dari masa yang dapat dikatakan sezaman. Buku Roesdi djeung Misnem terbit pada paruh pertama abad ke-20. Sehubungan dengan periode itu, dapat diperbandingkan dengan sebuah potret yang memperlihatkan sosok anak-anak Bandung di dasawarsa 1930-an sebagaimana terlihat pada gambar 7 .

Apabila diperbandingkan sosok Rusdi dalam gambar de Bruin dan sosok anakanak Bandung dalam potret dari dasawarsa 1930-an tersebut, kiranya dapat dikatakan bahwa citra Rusdi pada dasarnya dapat menimbulkan kesan realistis. Perhatikan raut, postur dan busana anak-anak dalam potret di atas, yang sedikit 
banyak tidak begitu berbeda dengan apa yang tampak dalam gambar sosok Rusdi. Dalam hal busana, misalnya, dapat diperhatikan bahwa ikat kepala serta model baju dan celana yang dikenakan oleh sekawanan anak-anak dalam potret tersebut serupa dengan apa yang dikenakan oleh Rusdi. Kalaupun dalam potret tersebut terlihat adanya anak yang mengenakan sarung, baik yang diselendangkan maupun yang dirungkupkan seperti mantel. Demikian pula dalam hal raut, bentuk wajah yang cenderung tirus, sebagaimana bentuk wajah Rusdi, tampaknya merupakan pemandangan umum pada masanya.

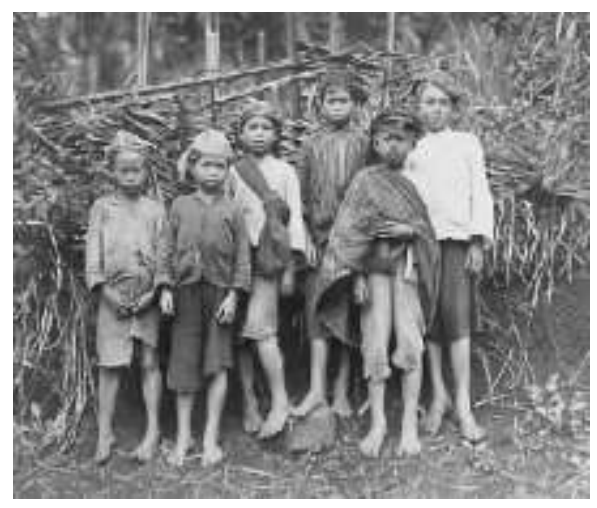

Gambar 7 Anak-anak Bandung pada 1930-an (foto koleksi KITLV, Leiden).

Dengan demikian, bagian dari gambar sosok Rusdi yang kiranya sangat menarik dan penting ditilik adalah kedua tangannya, yakni tangan kanan yang memegang pisang dan tangan kiri yang memegang tongkat. Citra pisang dan tongkat sudah barang tentu dibuat sebagai konkritisasi dari deskripsi verbal tentang Rusdi yang dikatakan "tiada hentinya makan" dan suka "bermain di kebun". Dengan kata lain, citra pisang merupakan representasi dari makanan, sedangkan citra tongkat merupakan representasi dari cara mendapatkan makanan. Tidak semua pohon buah-buahan lazim dipanjat, apalagi oleh seorang anak yang umurnya baru tujuh tahun. Buah pisang lazimnya diambil dengan cara memotong tangkainya dengan pisau yang disambungkan pada sebatang tongkat.

Akan tetapi citra pisang bukanlah citra tanpa masalah, terutama apabila citra itu dilekatkan pada gambaran anak jajahan yang dibuat oleh orang Eropa sebagai bagian dari imperium yang pernah melangsungkan kolonialisme di Kepulauan Nusantara. Terlepas dari maksud pembuat gambar itu sendiri, citra pisang yang dilekatkan pada visualisasi anak jajahan tidak mustahil menimbulkan kesan penistaan. Pisang memang disukai oleh manusia, tetapi pisang juga disukai oleh kera. Visualisasi kera tidak jarang disertai dengan visualisasi makanan 
kegemarannya. Sampai di sini, tidak mustahil timbul pertanyaan, tidakkah orang Eropa dahulu kala cenderung melihat anak jajahan seperti kera?

Barangkali, pertanyaan seperti itu terasa berlebihan. Namun kita dapat mengingat Minke, tokoh utama dalam Bumi Manusia (1981), novel termasyhur karya mendiang Pramoedya Ananta Toer. Dapat dikutip beberapa bagian deskripsi buku pertama dari Trilogi Pulau Buru itu, sebagai berikut:

Memang bukan mauku bernama atau dinamai Minke. Aku sendiri tak kurang-kurang heran. Ceritanya memang agak berbelit, dimulai kala aku memasuki E.L.S. tanpa mengetahui Belanda sepatah pun. Meneer Ben Rooseboom, guruku yang pertama-tama, sangat jengkel padaku. Tak pernah aku dapat menjawab pertanyaannya kecuali dengan tangis dan lolong. Namun setiap hari seorang opas mengantarku ke sekolah terbenci itu juga.

$\cdots$

Meneer Rooseboom melotot menakutkan, membentak:

"Diam kau, monk.... Minke!"

...

Kemudian mulailah kami mendapat pelajaran Inggris. Enam bulan lamanya, dan aku temukan kesamaan bunyi dan huruf pada namaku. Aku mulai kenangkan kembali: mata melotot dan alis yang hendak copot dari muka yang lebar itu pasti menyatakan sesuatu yang buruk. Dan aku teringat pada Meneer Rooseboom yang agak ragu menyebutkan nama itu. Dengan kecut pikiranku menduga, dulu ia mungkin bermaksud memaki aku dengan kata monkey. [14]

\section{Simpulan}

Uraian di atas kiranya dapat memberikan gambaran perhatian seniman Belanda terhadap kaum pribumi dan kompleksitas masalah sosial yang terjadi semasa pemerintahan kolonial, terutama kehidupan anak-anak pribumi yang amat bersahaja. Tergambar dalam beberapa ilustrasi sebagai bentuk persepsi orang Eropa yang merendahkan anak-anak negara jajahan.

Rangkaian gambar ilustrasi karya W.K. de Bruin dalam buku Roesdi djeung Misnem dapat menjadi rekaman kondisi kehidupan sebenarnya anak-anak pribumi pada masa itu. Paparan ini belum sepenuhnya mengupas fenomena permasalahan yang menjadi pokok perhatian dalam ilustrasi buku tersebut secara keseluruhan, terutama sikap dan pandangan seniman Belanda terhadap anak-anak negara jajahan, dan baru merupakan upaya memetakan dan membandingkannya dengan foto-foto kehidupan sosial anak-anak pribumi yang 
dipotret pada masa kolonial. Diharapkan, pada penelitian lanjutan akan memperoleh kesempatan untuk menelaah kompleksitas masalah ilustrasi buku karya W.K. de Bruin dalam kaitannya dengan visualisasi manusia dan alam Sunda pada zaman kolonial secara utuh dan menyeluruh.

\section{Referensi}

[1] Sabana, Setiawan \& Setiawan Hawe. 2005. Legenda Kertas: Menelusuri Jalan sebuah Peradaban Kiblat Buku Utama, hal. 76.

[2] Ajip Rosidi. 1966. Dur Pandjak! , Pusaka Sunda, hal. 42

[3] Leo Haks. 1995. Lexicon of Foreign Artists who Visualized Indonesia (1600-1950) Archipelago Press, hal. 50

[4] Haryadi Suadi. 2000. Onong Nugraha: Sebuah Riak dalam Gelombang Sejarah Seni Ilustrasi di Indonesia, Dewan Kesenian Daerah Jawa Barat.

[5] Bibliotheek KITLV, Leiden, pada Januari 2007.

[6] Keterangan dari Dr. Julian Millie, antropolog yang mengajar di Monash University dan pernah menolong penulis mencarikan buku Roesdi djeung Misnem.

[7] Wawancara penulis dengan salah seorang anak R. Djajadiredja, Hj. Titi Arifin Djajadiredja (78), di Bandung, 17 November 2006.

[8] Poesaka Soenda (No. 8-9, Agustus-September 1927, Tahun ke-5), hal. 141-149.

[9] Volksalmanak Soenda 1939 Tahoen ka XXI terbitan Bale Poestaka, Batavia. 1938. hal. 124, dalam kolom "Boekoe2 kaloearan J.B. Wolters, Groningen, Batavia.

[10] Burgers, Jacqueline. 1977. Brood op de Leesplank, A.W. Sijthoff, Leiden, hal. 97.

[11] www.wikipedia.com (diakses 6 September 2006)

[12] Burgers, Op. Cit., hal. 101.

[13] Roesdi djeung Misnem, jilid 1, cet. ke-2 (Blankwaardt \& Schoonhoven, tanpa tahun) hal. 9-10.

[14] Pramoedya Ananta Toer. 1981. Bumi Manusia .Hasta Mitra, hal. 28-29. 